\title{
Market Discipline in the Interbank Market: Evidence from an Emerging Country
}

\author{
DUNG VIET TRAN \\ Saigon International School of Business \\ Banking University Ho Chi Minh City \\ 36 Ton That Dam Str., District 1, Ho Chi Minh City 700000 \\ VIETNAM \\ CHI HUU LU \\ Saigon International School of Business \\ Banking University Ho Chi Minh City \\ 36 Ton That Dam Str., District 1, Ho Chi Minh City 700000 \\ VIETNAM
}

\begin{abstract}
This study provides one of the first evidence of the market discipline in the interbank market of the Vietnamese banking system after the global financial crisis. Based on the data of 19 commercial banks listed in Vietnam from 2010 to 2019, our empirical results suggest a weak interbank discipline in the Vietnamese banking system. Banks seem to be interested in the liquidity ratio of their fellows, especially for smaller banks, whereas they pay more attention to asset quality in the case of larger banks. We believe our study is of interest to regulators and policymakers in Vietnam..
\end{abstract}

Key-Words: - Market discipline, Interbank market, Vietnam commercial banks

Received: January 2, 2021. Revised: June 14, 2021. Accepted: June 29, 2021. Published: July 6, 2021.

\section{Introduction}

With unique characteristics from the natural opaqueness of assets, bank risks may spread national wide, or even internationally wide as we witness from the last global financial crisis. There have been many studies aimed at providing warnings and measures in setting up and minimizing the risks of the banking system. And the role of market discipline has been affirming over the recent years due to it contributes to controlling banking risk behavior and maintaining a healthy financial system (see more: the study of [1], [2]. Indeed, market discipline is the ability to reinforce minimum capital requirements (Pillar 1) and supervisory operational regulation (Pillar 2).

In general, most empirical studies have consensus on the existence of market discipline in the banking industry in both developed countries [3], [4] and emerging market nations [5]-[8]. However, the empirical studies on market discipline, especially in emerging markets, often emphasize the market discipline of depositors (see e.g. [9]-[11]).

In the scope of this research, we conduct one of the first examinations of the Vietnamese interbank market through the quantitative mechanism. Using the data set of 19 listed commercial banks over the period 2010 - 2019, our study provides consistent evidence of the existence of market discipline in the Vietnamese interbank market after the 2007-2009 financial crisis. We provide a battery of sensitivity tests. We perform our investigation (i) with the inclusion of additional variables to mitigate the problem of omitted variables, (ii) with an alternative measure of the growth of interbank borrowing, as well as alternative sub-samples according to the different sizes, (iii) with the alternative econometric approach. We still obtain similar findings.

This paper contributes to the literature in several ways. To the best of our knowledge, this study provide one of the first evidence of the market discipline in the Vietnam interbank market. Our evidence suggest in general that market discipline in Vietnam interbank market is weak due to the implicit guarantees of Vietnamese government. The study documents that small banks are concerned of the liquid assets of other banks, whereas large banks pay more attention for size and quality of assets. We strongly believe that our results are of interest of regulators and policymakers, who are making efforts to reform the domestic banking system and to move towards the comprehensive application of Basel II standards. 
The next section reviews the literature. Section 3 describes the data and variables. Section 4 delineates the main results and robustness tests. Eventually, section 6 concludes the study.

\section{Literature Review}

[5] Suggest that in the emerging markets, market discipline of depositors has been the usually possible source and relatively common. With that in mind, the studies on interbank discipline in these markets are relatively scarce. However, the role of banks in the supervision and control of mutual risk behavior has been confirmed in many researches. Indeed, [12] note that banks are particularly familiar with their own business and will therefore have a certain advantage in recognizing probable bank failures. In addition, in the case when a bank is in a bad situation (even bank run), there will be more likely identified the first by the other banks rather than those involved such as depositors [13].

In general, the empirical studies on the interbank discipline adopt two mechanisms: the price and the quantity. Accordingly, banks with higher risks will pay higher interest rates and receive lower credits. [14] is considered as one of the pioneers who conduct the empirical test on monitoring bank performance by their fellows. The author has tested experimentally through the price mechanism for commercial banks in the US. The results show that banks with high profitability and capital ratio, as well as low NPLs, will approach lower overnight rates in the interbank market. [15] also finds similar results in which banks having higher risk will have to pay higher interest rates and will be less able to accessing capital in the interbank market.

By contrast, the evidence discovered by [16] is not strong about the interbank market discipline in the Mexican market over the period spanning $12 / 2008$ to $09 / 2012$ through both quantity and price mechanism. The author uses the implicit interest rate to measure the price mechanism and the interbank borrowing to estimate the quantity mechanism. These results reinforce the previous study of [17] when the author argues that the banks with greater exposure to the interbank market are those that do not have healthy bedrocks and thus contrary to the market discipline hypothesis.

In our current efforts to scour the studies on Vietnamese interbank discipline, we almost do not find any empirical research conducted. Hence, this paper will fill this critical research gap.

\section{Data and Variables}

The financial data are collected and calculated from the audited financial statements of 19 commercial banks listed on HOSE, HNX, and UPCOM in the period 2010-2019. Meanwhile, the macroeconomic data are sourced from the World Bank (WB), State Bank of Vietnam (SBV) during the same period. In addition, we divide into different sets of samples including the 5 largest commercial banks and the rest of 11 commercial banks (except for the 3 stateowned commercial banks in the sample) to measure the level of interbank discipline following the effects of bank size. All variables were winsorized at $1 \%$ and $99 \%$ for concerns of outliers.

Due to the data on lending interest rates between commercial banks cannot access, thus we use the growth of interbank borrowing as a dependent variable to test interbank discipline through quantity mechanism. In addition, according to [16], we replace the dependent variable by using the ratio of interbank borrowing to total deposits to examine further the quantity-based discipline mechanism.

For bank fundamental variables, we evaluate the quality of the bank through the following indices: total assets (SIZE), equity ratio (CAPITAL), liquid assets ratio (LIQUID), loan loss reserve ratio (LLR), operating efficiency ratio (EXPENSE), the ZSCORE (bank risk).

We use the annual average 9-month interbank rate (INRATE) to control the possible effects of the monetary regulator. We use the gross domestic product (GDP) growth, the inflation rate, and the annual average of VND/USD exchange rate as representative macroeconomic variables since [18] strongly alarms that the market discipline assessment needs to consider systemic risks through macroeconomic variables.

Accordingly, the expected impact of the explanatory variables on GRINBANK of commercial banks listed in Vietnam and the descriptions of the related variables are shown in Table 1.Our main baseline model is as follows:

$$
\begin{aligned}
\text { GRINBANK }= & \alpha+\beta_{1} \text { CAPITAL }_{i, t}+\beta_{2} \text { SIZE }_{i, t} \\
& +\beta_{3} \text { LIQUID }_{i, t}+\beta_{4} L L R_{i, t} \\
& +\beta_{5} \text { ZSCORE }_{i, t}+\beta_{6} \text { EXPENSE }_{i, t} \\
& +\beta_{7} \text { INRATE }_{i, t}+\varepsilon_{i, t}
\end{aligned}
$$

Accordingly, the expected impact of the explanatory variables on GRINBANK of commercial banks listed in Vietnam and the descriptions of the related variables are shown in Table 1. 
Table 1. Variables definitions and expectations

\begin{tabular}{|c|c|c|c|}
\hline Dependent variable & Definitions & \multicolumn{2}{|l|}{ Data source } \\
\hline GRINBANK & $\begin{array}{l}\text { The annual growth of interbank } \\
\text { borrowing }\end{array}$ & \multicolumn{2}{|c|}{ The audited financial statements } \\
\hline $\begin{array}{l}\text { Alternative } \\
\text { dependent variable }\end{array}$ & Definitions & \multicolumn{2}{|l|}{ Data source } \\
\hline INBANKDEPO & $\begin{array}{l}\text { The annual ratio of total interbank } \\
\text { borrowing to total deposits }\end{array}$ & \multicolumn{2}{|c|}{ The audited financial statements } \\
\hline Independent variables & Definitions & Data source & Pred sign \\
\hline GRGDP & The annual GDP growth of Vietnam & WB & $(+)$ \\
\hline IFLR & The annual inflation rate & WB & $(-)$ \\
\hline EXCR & $\begin{array}{l}\text { The natural logarithm of annual average } \\
\text { of VND/USD exchange rate }\end{array}$ & WB & $(-)$ \\
\hline SIZE & $\begin{array}{l}\text { The natural logarithm of gross total } \\
\text { assets }\end{array}$ & $\begin{array}{l}\text { The audited } \\
\text { financial statements }\end{array}$ & $(+)$ \\
\hline LIQUID & $\begin{array}{l}\text { The ratio short-term assets to total } \\
\text { assets }\end{array}$ & $\begin{array}{l}\text { The audited } \\
\text { financial statements }\end{array}$ & $(+)$ \\
\hline CAPITAL & $\begin{array}{l}\text { Book value of equity over gross total } \\
\text { assets }\end{array}$ & $\begin{array}{l}\text { The audited } \\
\text { financial statements }\end{array}$ & $(+)$ \\
\hline LLR & The loan loss reserve ratio & $\begin{array}{l}\text { The audited } \\
\text { financial statements }\end{array}$ & $(-)$ \\
\hline ZSCORE & $\begin{array}{l}\text { The sum of average ROA and the } \\
\text { equity-to-total assets ratio, divided by } \\
\text { the standard deviation of ROA. A two- } \\
\text { year moving windows is used to } \\
\text { estimate the average and the standard } \\
\text { deviation of ROA }\end{array}$ & $\begin{array}{l}\text { The audited } \\
\text { financial statements }\end{array}$ & $(-)$ \\
\hline EBLTA & $\begin{array}{l}\text { Income before taxes, provisions } \\
\text { recognized in income over gross total } \\
\text { assets }\end{array}$ & $\begin{array}{l}\text { The audited } \\
\text { financial statements }\end{array}$ & $(+)$ \\
\hline EBLTE & $\begin{array}{l}\text { Income before taxes, provisions } \\
\text { recognized in income over gross total } \\
\text { equity }\end{array}$ & $\begin{array}{l}\text { The audited } \\
\text { financial statements }\end{array}$ & $(+)$ \\
\hline STATE & $\begin{array}{l}\text { A dummy variable equal one if the } \\
\text { commercial bank is owned by the state } \\
\text { and equal } 0 \text { otherwise }\end{array}$ & $\begin{array}{l}\text { The audited } \\
\text { financial statements }\end{array}$ & $(+)$ \\
\hline EXPENSE & $\begin{array}{l}\text { The ratio of total operating expenses to } \\
\text { total operating income before } \\
\text { provisions and taxes }\end{array}$ & $\begin{array}{l}\text { The audited } \\
\text { financial statements }\end{array}$ & $(-)$ \\
\hline INRATE & $\begin{array}{l}\text { The annual average 9-month interbank } \\
\text { rate }\end{array}$ & SBV & $(-)$ \\
\hline
\end{tabular}

\section{Main Results}

\subsection{Summary Statistics}

Table 2 presents descriptive statistics of variables with 190 observations of 19 commercial banks from 2010 to 2019. Accordingly, the average GRINBANK in the sample is $55.5 \%$ with standard deviation of 1.85 and the maximum value is up to $139.3 \%$ showing a strongly growth trend for capital mobilization through the interbank market channel and there is a large gap between commercial banks in the past 10 years. On the other hand, the
INBANKDEPO shows the lower average of $28.4 \%$, however it also reflects the interbank market playing a certain important role in mobilizing capital resources of commercial banks. Notably, SIZE has the certain large standard deviation of 1.10 while the average (logarithm) is 32.51, which depicts the relatively large difference in size among commercial banks in the data. The average EXPENSE is about $60.5 \%$ and the largest value is $185.5 \%$ in the case of National Citizen commercial bank in 2013. 
Table 2. Summary Statistics

This table reports summary statistics for the main sample of V.N. commercial banks used in the analysis. All financial variables are winsorized at $1 \%$ and $99 \%$ levels.

\begin{tabular}{|c|c|c|c|c|c|}
\hline & $\begin{array}{l}\text { (1) } \\
\mathrm{N}\end{array}$ & $\begin{array}{c}(2) \\
\text { mean }\end{array}$ & $\begin{array}{l}(3) \\
\text { sd } \\
\end{array}$ & $\begin{array}{l}\text { (4) } \\
\text { min }\end{array}$ & $\begin{array}{l}(5) \\
\max \end{array}$ \\
\hline GRINBANK & 190 & 0.555 & 1.854 & -0.941 & 13.93 \\
\hline INBANKDEPO & 190 & 0.284 & 0.238 & 0.00880 & 1.339 \\
\hline INRATE & 190 & 0.459 & 0.239 & 0.108 & 0.835 \\
\hline GRGDP & 190 & 0.0631 & 0.00596 & 0.0525 & 0.0708 \\
\hline IFLR & 190 & 0.0619 & 0.0488 & 0.00879 & 0.187 \\
\hline EXCR & 190 & 9.968 & 0.0583 & 9.832 & 10.05 \\
\hline CAPITAL & 190 & 0.0873 & 0.0351 & 0.0415 & 0.253 \\
\hline SIZE & 190 & 32.51 & 1.102 & 30.17 & 34.81 \\
\hline LIQUID & 190 & 0.151 & 0.0805 & 0.0241 & 0.381 \\
\hline LLR & 190 & -0.0193 & 0.0662 & -0.390 & 0.0254 \\
\hline ZSCORE & 190 & 2.596 & 5.086 & 0.0225 & 35.66 \\
\hline EBLTA & 190 & 0.0169 & 0.00997 & 0.00161 & 0.0633 \\
\hline EBLTE & 190 & 0.209 & 0.120 & 0.0151 & 0.589 \\
\hline EXPENSE & 190 & 0.605 & 0.278 & 0.287 & 1.855 \\
\hline
\end{tabular}

Table 3. Correlation matrix

\begin{tabular}{lccccccc}
\hline Variables & GRINBANK & CAPITAL & SIZE & LIQUID & LLR & ZSCORE & EXPENSE \\
\hline CAPITAL & 0.093 & 1.000 & & & & & \\
& 0.200 & & & & & & \\
SIZE & $-0.155^{*}$ & $-0.604^{*}$ & 1.000 & & & & \\
& 0.033 & 0.000 & & & & & \\
LIQUID & $0.174^{*}$ & $0.181^{*}$ & $-0.240^{*}$ & 1.000 & & & \\
& 0.016 & 0.012 & 0.001 & & & & \\
LLR & $(0.004)$ & 0.053 & 0.118 & $0.144^{*}$ & 1.000 & & \\
& 0.951 & 0.468 & 0.105 & 0.047 & & & \\
ZSCORE & $(0.047)$ & 0.050 & 0.085 & $(0.061)$ & $-0.205^{*}$ & 1.000 & \\
EXPENSE & 0.517 & 0.491 & 0.246 & 0.406 & 0.005 & & \\
& 0.086 & 0.065 & $-0.379^{*}$ & $-0.143^{*}$ & $-0.273^{*}$ & $(0.087)$ & 1.000 \\
INRATE & 0.238 & 0.370 & 0.000 & 0.050 & 0.000 & 0.233 & \\
& $(0.001)$ & $-0.207^{*}$ & $0.199^{*}$ & $-0.483^{*}$ & $-0.300^{*}$ & 0.103 & $0.373^{*}$ \\
& 0.990 & 0.004 & 0.006 & 0.000 & 0.000 & 0.159 & 0.000 \\
\hline
\end{tabular}

* shows significance at the $5 \%$ level 


\subsection{Correlation Matric}

Table 3 presents the correlation coefficients between the variables in the study sample and the variables including SIZE AND LIQUID are statistically significant at 5\% in each pair correlation with GRINBANK besides the remaining variables are not statistically significant. Additionally, SIZE has a

\subsection{Results}

Table 4 presents the results of multivariate regression with whole sample data using the ordinary least squares regression method (OLS). In models (1) to (4), the dependent variable is GRINBANK. In our baseline model (Model (1)), we observe that LIQUID has a strong positive impact on GRINBANK with a significance level of $5 \%$ in accordance with our expectation. The rest of the variables do not produce the expected results and are all statistically insignificant except for CAPITAL and ZSCORE.

In model (2), we add STATE dummy variable to measure the impact of State-owned banks on the behavior of banks. The result is almost unchanged comparing to model (1), although STATE positively affects GRINBANK, however, it is not statistically significant.

In model (3), we continue to add the ratio of earnings before loan loss provisions (EBLTA and EBLTE) to Model (1) to control for the impacts of bank profits. The results in model (3) are similar to that of model (1) with a stronger positive effect LIQUID. In model (4), we also continue to add 3 macroeconomic variables (GDP, IFLR and EXCR) to model (1) to estimate the effects of macroeconomic conditions that partially influence the behavior of the banks. The results in model (4) show that only EXCR has remarkably negative effect on GRINBANK with the significance level of $1 \%$ while the other variables are not statistically significant although LIQUID also haspositive effect.

From Model (5) - (8), we use INBANKDEPO as alternative measure of dependent variable. Except for LIQUID has a $1 \%$ positive effect, the results show somewhat differences. SIZE in all 4 models has the negative effect of $1 \%$ on INBANKDEPO. This contradicts the expectation, but it also shows that large-scale banks tend to reduce borrowing from the interbank market. In addition, model (7) shows that EBLTA has the significant $1 \%$ positive positive effect on INBANKDEPO while CAPITAL presents the opposite trend. In model (8), CAPITAL is negative influence at a weaker level with a $10 \%$ significance level while both INRATE and IFLR are positive affect and have a $10 \%$ significance level. negative effect and LIQUID has a positive effect on GRINBANK. From these correlations, we will conduct to build some main ways to test the robustness of the baseline model through different indicators of the explanatory variables shown in the next content.

From our perspective, when the equity resources of commercial banks are strengthened that can lead to reducing in the demands for borrowing from the interbank market. On the other hand, when macroeconomic conditions fluctuate (for example, increasing inflation), the needs to compensate for liquidity from the interbank market will be greater. And this partly shows the results in model (8).

In models (9) - (10), we use 2SLS method to test futher robustness of our findings in the previous models. Both models show similar results in model (1) that depict considerable and positive effects of LIQUID, in which model (10) presents LIQUID with a statistically significant level of $1 \%$.

Next, we provide further examinations to the evidence of market discipline in the interbank markets under different circumstances. Table 5 presents the regression results with the sample including the 5 largest commercial banks (excluding 03 state-owned commercial banks in the whole sample). In model (11) - (13), the dependent variables are GRINBANK. In model (14) - (16), the dependent variables are INBANKDEPO. Accordingly, from model (11) - (13), the results show that LLR has remarkably negative impact on GRINBANK at the $1 \%$ significance level while EXPENSE also has similar effect, but at a significant level of $10 \%$, and is only shown in model (11) that is consistent with expectations. However, the remaining variables are not statistically significant.

The results in model (14) - (16) show a negative impact SIZE at $5 \%$ and $1 \%$ significance level. In addition, EXPENSE has a negative effect at 5\% significance level in model (14) besides EBLTA affect significantly positive effect on INBANKDEPO but only at a significance level of $10 \%$ in model (15). Again, these results are consistent with expectations. Even thought, ZCORE and EXCR are contrary to expectations in model (15) and model (16), but only at a significant level of $10 \%$, and ZSCORE has negligible impact. In brief, the results from Table (5) suggest that large banks seem to be more concerned with asset quality through the LLR indicator when making lending decisions in the interbank market. 
Table 4. The quantity-based mechanism of market discipline with full sample

\begin{tabular}{|c|c|c|c|c|c|c|c|c|c|c|}
\hline & \multicolumn{4}{|c|}{ The dependent variable: GRINBANK } & \multicolumn{4}{|c|}{ The dependent variable: INBANKDEPO } & \multirow{2}{*}{$\begin{array}{c}\text { 2SLS-GRINBANK } \\
\text { Model } 9\end{array}$} & \multirow{2}{*}{$\begin{array}{c}\text { 2SLS-INBANKDEPO } \\
\text { Model } 10\end{array}$} \\
\hline & Model 1 & Model 2 & Model 3 & Model 4 & Model 5 & Model 6 & Model 7 & Model 8 & & \\
\hline CAPITAL & $\begin{array}{c}0.767 \\
(3.533)\end{array}$ & $\begin{array}{c}0.644 \\
(3.803)\end{array}$ & $\begin{array}{c}2.639 \\
(5.865)\end{array}$ & $\begin{array}{c}0.660 \\
(4.041)\end{array}$ & $\begin{array}{l}-0.669 \\
(0.455)\end{array}$ & $\begin{array}{l}-0.633 \\
(0.459)\end{array}$ & $\begin{array}{c}-2.011 * * * \\
(0.631)\end{array}$ & $\begin{array}{l}-0.758 * \\
(0.446)\end{array}$ & $\begin{array}{l}-13.97 \\
(33.53)\end{array}$ & $\begin{array}{l}-2.757 \\
(3.516)\end{array}$ \\
\hline SIZE & $\begin{array}{l}-0.183 \\
(0.235)\end{array}$ & $\begin{array}{l}-0.201 \\
(0.341)\end{array}$ & $\begin{array}{l}-0.272 \\
(0.229)\end{array}$ & $\begin{array}{l}-0.104 \\
(0.260)\end{array}$ & $\begin{array}{c}-0.0803 * * * \\
(0.0176)\end{array}$ & $\begin{array}{c}-0.0751 * * * \\
(0.0255)\end{array}$ & $\begin{array}{c}-0.0947 * * * \\
(0.0181)\end{array}$ & $\begin{array}{c}-0.0838 * * * \\
(0.0168)\end{array}$ & $\begin{array}{l}-0.508 \\
(0.752)\end{array}$ & $\begin{array}{c}-0.126 \\
(0.0808)\end{array}$ \\
\hline LIQUID & $\begin{array}{l}4.667 * * \\
(2.272)\end{array}$ & $\begin{array}{l}4.643 * * \\
(2.295)\end{array}$ & $\begin{array}{l}4.787 * * \\
(2.301)\end{array}$ & $\begin{array}{c}3.058 \\
(2.106)\end{array}$ & $\begin{array}{l}1.726 * * * \\
(0.272)\end{array}$ & $\begin{array}{c}1.733 * * * \\
(0.281)\end{array}$ & $\begin{array}{c}1.792 * * * \\
(0.270)\end{array}$ & $\begin{array}{l}1.591 * * * \\
(0.271)\end{array}$ & $\begin{array}{l}4.572 * * \\
(1.938)\end{array}$ & $\begin{array}{l}1.713 * * * \\
(0.272)\end{array}$ \\
\hline LLR & $\begin{array}{c}0.427 \\
(1.594)\end{array}$ & $\begin{array}{c}0.439 \\
(1.658)\end{array}$ & $\begin{array}{c}0.259 \\
(1.711)\end{array}$ & $\begin{array}{l}-0.143 \\
(1.296)\end{array}$ & $\begin{array}{c}0.184 \\
(0.176)\end{array}$ & $\begin{array}{c}0.181 \\
(0.175)\end{array}$ & $\begin{array}{c}0.119 \\
(0.147)\end{array}$ & $\begin{array}{c}0.108 \\
(0.181)\end{array}$ & $\begin{array}{c}1.363 \\
(2.727)\end{array}$ & $\begin{array}{c}0.317 \\
(0.219)\end{array}$ \\
\hline ZSCORE & $\begin{array}{l}-0.0120 \\
(0.0162)\end{array}$ & $\begin{array}{l}-0.0117 \\
(0.0160)\end{array}$ & $\begin{array}{l}-0.00689 \\
(0.0201)\end{array}$ & $\begin{array}{l}-0.0117 \\
(0.0174)\end{array}$ & $\begin{array}{l}-0.00170 \\
(0.00213)\end{array}$ & $\begin{array}{l}-0.00180 \\
(0.00209)\end{array}$ & $\begin{array}{l}-0.00165 \\
(0.00189)\end{array}$ & $\begin{array}{l}-0.00153 \\
(0.00213)\end{array}$ & & \\
\hline EXPENSE & $\begin{array}{c}0.200 \\
(1.445)\end{array}$ & $\begin{array}{c}0.188 \\
(1.467)\end{array}$ & $\begin{array}{c}0.386 \\
(1.613)\end{array}$ & $\begin{array}{l}0.0507 \\
(1.760)\end{array}$ & $\begin{array}{c}-0.0290 \\
(0.102)\end{array}$ & $\begin{array}{c}-0.0254 \\
(0.104)\end{array}$ & $\begin{array}{l}0.0338 \\
(0.102)\end{array}$ & $\begin{array}{c}-0.0782 \\
(0.122)\end{array}$ & $\begin{array}{c}-0.0963 \\
(0.969)\end{array}$ & $\begin{array}{r}-0.0709 \\
(0.129)\end{array}$ \\
\hline INRATE & $\begin{array}{c}0.916 \\
(1.210)\end{array}$ & $\begin{array}{c}0.931 \\
(1.288)\end{array}$ & $\begin{array}{c}0.963 \\
(1.232)\end{array}$ & $\begin{array}{c}2.077 \\
(1.663)\end{array}$ & $\begin{array}{c}0.0764 \\
(0.0855)\end{array}$ & $\begin{array}{c}0.0723 \\
(0.0872)\end{array}$ & $\begin{array}{c}0.0617 \\
(0.0839)\end{array}$ & $\begin{array}{l}0.189 * \\
(0.106)\end{array}$ & $\begin{array}{c}0.932 \\
(0.736)\end{array}$ & $\begin{array}{c}0.0787 \\
(0.0814)\end{array}$ \\
\hline EBLTA & & & $\begin{array}{l}-15.02 \\
(30.41)\end{array}$ & & & & $\begin{array}{c}9.603 * * * \\
(3.036)\end{array}$ & & & \\
\hline EBLTE & & & $\begin{array}{c}2.578 \\
(3.677)\end{array}$ & & & & $\begin{array}{l}-0.438 \\
(0.267)\end{array}$ & & & \\
\hline STATE & & $\begin{array}{l}0.0604 \\
(0.467)\end{array}$ & & & & $\begin{array}{l}-0.0177 \\
(0.0459)\end{array}$ & & & & \\
\hline GRGDP & & & & $\begin{array}{c}32.83 \\
(29.49)\end{array}$ & & & & $\begin{array}{l}0.0833 \\
(3.371)\end{array}$ & & \\
\hline IFLR & & & & $\begin{array}{c}0.812 \\
(3.896)\end{array}$ & & & & $\begin{array}{l}0.926^{*} \\
(0.491)\end{array}$ & & \\
\hline EXCR & & & & $\begin{array}{c}-10.78 * * * \\
(3.681)\end{array}$ & & & & $\begin{array}{c}0.0557 \\
(0.380)\end{array}$ & & \\
\hline Constant & $\begin{array}{c}5.223 \\
(8.187)\end{array}$ & $\begin{array}{c}5.810 \\
(11.45)\end{array}$ & $\begin{array}{c}7.515 \\
(7.586)\end{array}$ & $\begin{array}{c}107.8 * * * \\
(36.00)\end{array}$ & $\begin{array}{c}2.685 * * * \\
(0.622)\end{array}$ & $\begin{array}{c}2.513 * * * \\
(0.877)\end{array}$ & $\begin{array}{c}3.155 * * * \\
(0.620)\end{array}$ & $\begin{array}{c}2.186 \\
(3.858)\end{array}$ & $\begin{array}{c}17.27 \\
(27.82)\end{array}$ & $\begin{array}{c}4.391 \\
(2.989)\end{array}$ \\
\hline Obs & 190 & 190 & 190 & 190 & 190 & 190 & 190 & 190 & 190 & 190 \\
\hline R-squared & 0.057 & 0.058 & 0.061 & 0.113 & 0.488 & 0.489 & 0.521 & 0.502 & 0.012 & 0.433 \\
\hline
\end{tabular}

Robust standard errors in parentheses $* * * \mathrm{p}<0.01, * * \mathrm{p}<0.05, * \mathrm{p}<0.1$ 
Table 5. The quantity-based mechanism of market discipline with large banks

\begin{tabular}{|c|c|c|c|c|c|c|}
\hline & \multicolumn{3}{|c|}{ The dependent variable: GRINBANK } & \multicolumn{3}{|c|}{ The dependent variable: INBANKDEPO } \\
\hline & Model 11 & Model 12 & Model 13 & Model 14 & Model 15 & Model 16 \\
\hline \multirow[t]{2}{*}{ CAPITAL } & -4.728 & 22.30 & -3.417 & 0.504 & -2.972 & 0.297 \\
\hline & $(10.64)$ & $(19.50)$ & $(10.98)$ & $(0.632)$ & $(2.351)$ & $(0.697)$ \\
\hline \multirow[t]{2}{*}{ SIZE } & -0.0189 & 0.0417 & 0.405 & $-0.144 * *$ & $-0.172 * * *$ & $-0.307 * * *$ \\
\hline & $(0.273)$ & $(0.328)$ & $(0.600)$ & $(0.0571)$ & $(0.0614)$ & $(0.100)$ \\
\hline \multirow[t]{2}{*}{ LIQUID } & 2.373 & 1.374 & -1.426 & 0.508 & 0.635 & 0.651 \\
\hline & $(2.391)$ & (3.020) & $(3.431)$ & $(0.368)$ & $(0.397)$ & (0.689) \\
\hline \multirow[t]{2}{*}{ LLR } & $-8.196 * * *$ & $-9.797 * * *$ & $-6.539 * * *$ & -0.0914 & -0.263 & -0.199 \\
\hline & (1.668) & $(2.047)$ & $(1.412)$ & $(0.208)$ & $(0.188)$ & $(0.209)$ \\
\hline \multirow[t]{2}{*}{ ZSCORE } & 0.0137 & 0.00928 & 0.0203 & 0.00158 & $0.00510 *$ & 0.000195 \\
\hline & $(0.0176)$ & $(0.0198)$ & $(0.0177)$ & $(0.00251)$ & $(0.00299)$ & $(0.00246)$ \\
\hline \multirow[t]{2}{*}{ EXPENSE } & $-1.227 *$ & -0.898 & -0.603 & $-0.182 * *$ & -0.0302 & -0.134 \\
\hline & $(0.663)$ & $(0.612)$ & $(0.731)$ & $(0.0825)$ & $(0.0788)$ & $(0.0825)$ \\
\hline \multirow[t]{2}{*}{ INRATE } & -0.288 & -0.728 & -0.508 & -0.0988 & -0.144 & -0.102 \\
\hline & $(0.843)$ & $(0.958)$ & $(0.732)$ & $(0.132)$ & $(0.128)$ & $(0.133)$ \\
\hline \multirow[t]{2}{*}{ EBLTA } & & -95.12 & & & $12.56^{*}$ & \\
\hline & & $(81.52)$ & & & (6.914) & \\
\hline \multirow[t]{2}{*}{ EBLTE } & & 8.799 & & & -0.637 & \\
\hline & & $(7.564)$ & & & $(0.615)$ & \\
\hline \multirow[t]{2}{*}{ GRGDP } & & & 58.71 & & & 6.323 \\
\hline & & & (41.17) & & & (4.991) \\
\hline \multirow[t]{2}{*}{ IFLR } & & & -0.0386 & & & 0.696 \\
\hline & & & (4.134) & & & (1.024) \\
\hline \multirow[t]{2}{*}{ EXCR } & & & -11.19 & & & $1.614^{*}$ \\
\hline & & & $(7.443)$ & & & $(0.869)$ \\
\hline \multirow[t]{2}{*}{ Constant } & 1.832 & -2.467 & 95.79 & $4.976^{* * *}$ & $5.966 * * *$ & -6.193 \\
\hline & $(8.729)$ & (11.48) & $(58.90)$ & (1.908) & $(2.157)$ & $(6.338)$ \\
\hline Observations & 50 & 50 & 50 & 50 & 50 & 50 \\
\hline R-squared & 0.139 & 0.168 & 0.236 & 0.524 & 0.619 & 0.646 \\
\hline
\end{tabular}

Robust standard errors in parentheses

$* * * \mathrm{p}<0.01, * * \mathrm{p}<0.05, * \mathrm{p}<0.1$ 
Table 6. The quantity-based mechanism of market discipline with small banks

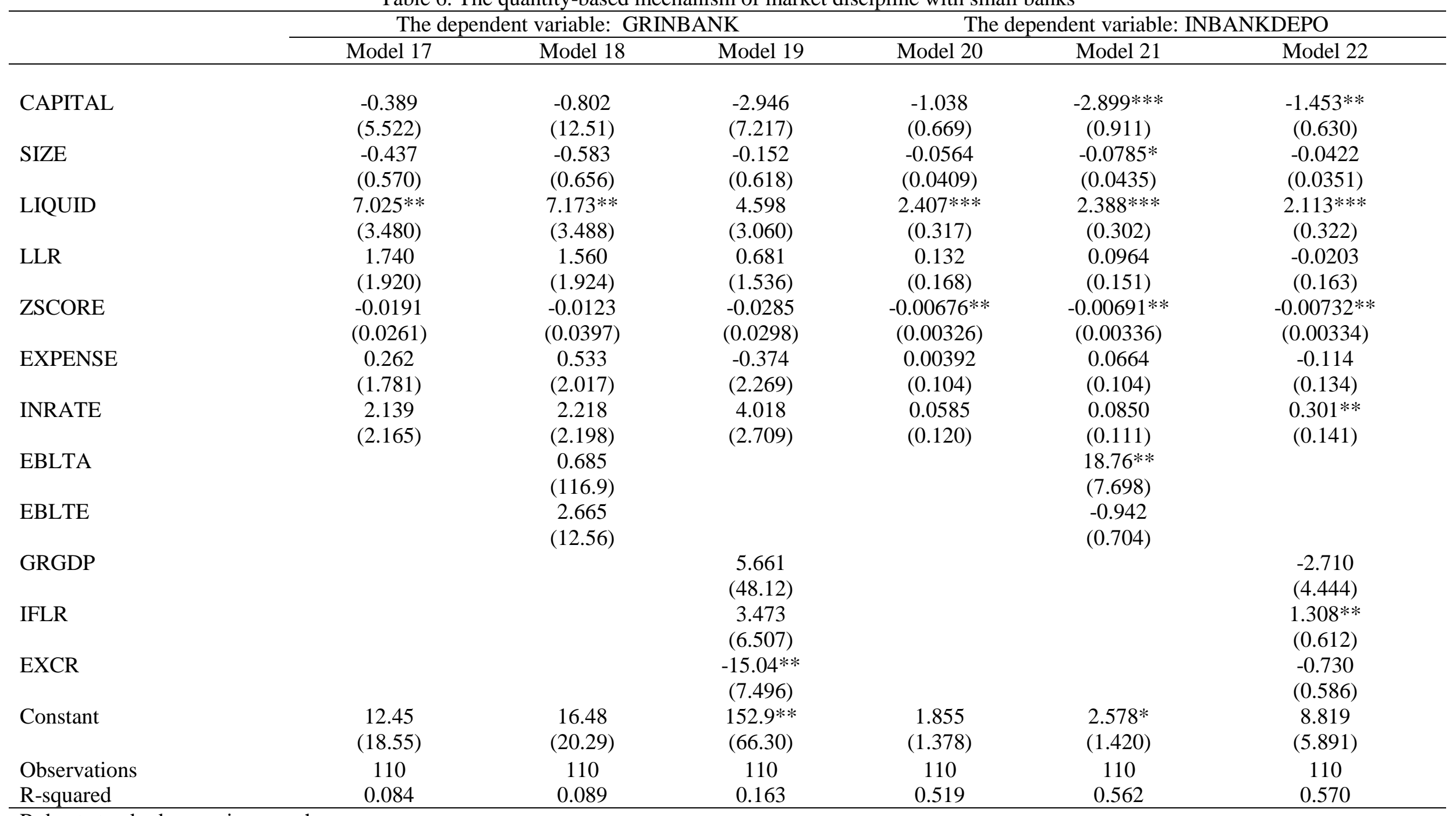

Robust standard errors in parentheses

$* * * \mathrm{p}<0.01, * * \mathrm{p}<0.05, * \mathrm{p}<0.1$ 
Table 6 presents the regression results with the sample including the 11 small commercial banks. In model (17) - (19), the dependent variables are GRINBANK. In model (20) - (22), the dependent variables are INBANKDEPO. The results in the model (17) - (19) are similar to the model (1), (3), (4) in which LIQUID has positive impact in the model (17) - (18) besides EXCR in the model (19) has opposite effect. These variables show a stronger impact on GRINBANK than model (1), (3), (4) and have a significance level of 5\%. Model (20) - (22) give certain similar results with model (5), (7), (8), particularly LIQUID also has more positive influence on INBANKDEPO and is significant at $1 \%$ level.

It is worth noting that ZSCORE shows the opposite influences with 5\% statistical significance in all three models (20) - (22) although the level of impacts is negligible. In addition, SIZE only presents negative effect with $10 \%$ significance level in model (21) comparison with the results of model (5), (7), (8). The remaining variables, including: CAPITAL, EBLTA, INRATE and IFLR in Model (21) - (22) are similar to the results of model (7) (8) but with a stronger effect.

The results from Table (6) suggest that small banks seem to be more concerned with the liquidity of banks when making lending decisions in the interbank market since the coefficients on LIQUID are all positive and statistically significant at the $1 \%$ level (except for Model (19)). A speculative explanation of this evidence is related to the liquidity crisis in 2011-2012 when the interbank interest witnesses strong increase.

\section{Conclusion and Policy Implications}

The results documnt the market discipline among Vietnamese commercial banks after the 2007-2009 financial crisis does exist, but weak. Among the fundamental variables of the bank, except for the liquidity index (LIQUID) that is of considerable interest to banks, especially the smaller banks, the remaining variables do not seem to be of sufficient interest level. The asset quality (LLR) is quite noticeable by the larger banks besides the bank risk factor (ZSCORE) considered by the smaller banks, although the magnitude is negligible. The bank size together with the capital capacity are contrary to expectations but as we mentioned, when two factors are improved in banks, it can lead to a decrease in demands for the loan from the interbank market. However, along with other macroeconomic variables such as inflation and exchange rate as well as business performance, these variables have shown weak results throughout the regression estimates presented.

In summary, the evidence suggests a weak market discipline among Vietnamese banks. This is interesting since among banks stakeholders (depositors, shareholders, debtholders...), banks are considered to be the most capable to monitor their "peers" via the interbank markets thanks to the qualified human ressources and information advantages. Hence, we suggest that the State Bank of Vietnam (SBV) needs to enhance the market discipline from the interbank markets, and should provide clear signals to the market in case that banks are at risk of bankruptcy. In this paper, we evaluate market discipline among commercial banks through quantity mechanism, and thus, the mechanism of the price through interest rate and/or the implicit interest has not been considered. We hope that future studies will fill this vital research gap.

\section{References:}

[1] M. J. Flannery, "Using market information in prudential bank supervision: A review of the US empirical evidence," J. Money Credit Bank., pp. 273-305, 1998.

[2] M. J. K. D. Ceuster and N. Masschelein, "Regulating Banks through Market Discipline: A Survey of the Issues," J. Econ. Surv., vol. 17, no. 5, pp. 749-766, 2003, doi: 10.1046/j.14676419.2003.00212.x.

[3] M. Flannery and S. Nikolova, "Market discipline of US financial firms: Recent evidence and research issues," Mark. Discip. Ctries. Ind., pp. 87-100, 2004.

[4] A. N. Berger and R. Turk-Ariss, "Do Depositors Discipline Banks and Did Government Actions During the Recent Crisis Reduce this Discipline? An International Perspective," J. Financ. Serv. Res., vol. 48, no. 2, pp. 103-126, Aug. 2014, doi: 10.1007/s10693-014-0205-7.

[5] I. Hasan, K. Jackowicz, O. Kowalewski, and Ł. Kozłowski, "Market discipline during crisis: Evidence from bank depositors in transition countries," J. Bank. Finance, vol. 37, no. 12, pp. 5436-5451, Dec. 2013, doi: 10.1016/j.jbankfin.2013.06.007.

[6] E. D. Tovar-García, "Market discipline: a review of the Mexican deposit market," Lat. Am. Econ. Rev., vol. 23, no. 1, p. 6, Apr. 2014, doi: 10.1007/s40503-014-0006-2.

[7] M. Chima, A. Babajide, A. Omankhanlen, and B. Adejumo, "Development: Unconventional 
Monetary Policy on Bank Performance in Nigeria," WSEAS Trans. Environ. Dev., vol. 16, pp. 844-860, Dec. 2020, doi: 10.37394/232015.2020.16.87.

[8] F. Olokoyo, A. Isibor, A. Folasade, T. Adesina (Nee Oladeji), G. Osuma, and A. Mercy, "Financial Systems Theory: Banker-Customer Relationship and Nigerian Deposit Money Banks' Performance: An Empirical Investigation," WSEAS Trans. Syst. CONTROL, vol. 15, pp. 556-562, Oct. 2020, doi: $10.37394 / 23203.2020 .15 .54$.

[9] C. W. Calomiris and J. R. Mason, "Contagion and Bank Failures During the Great Depression: The June 1932 Chicago Banking Panic," Am. Econ. Rev., vol. 87, no. 5, pp. 863883, 1997.

[10] M. D. Hadad, A. Agusman, G. S. Monroe, D. Gasbarro, and J. K. Zumwalt, "Market discipline, financial crisis and regulatory changes: Evidence from Indonesian banks," $J$. Bank. Finance, vol. 35, no. 6, pp. 1552-1562, juin 2011, doi: 10.1016/j.jbankfin.2010.11.003.

[11] E. D. Tovar-García, "Market discipline in the Latin American banking system: Testing depositor discipline, borrower discipline, and the internal capital market hypothesis," Span. Rev. Financ. Econ., vol. 15, no. 2, pp. 78-90, Jul. 2017, doi: 10.1016/j.srfe.2017.07.001.

[12] C. W. Calomiris and C. M. Kahn, "The Efficiency of Self-Regulated Payments Systems: Learning from the Suffolk System," J. Money Credit Bank., vol. 28, no. 4, pp. 766797, 1996, doi: 10.2307/2077920.

[13] C. W. Calomiris and G. Gorton, "The origins of banking panics: models, facts, and bank regulation," in Financial markets and financial crises, University of Chicago Press, 1991, pp. 109-174. Accessed: Jan. 30, 2015. [Online]. Available:

http://www.nber.org/chapters/c11484.pdf

[14] C. Furfine, "Bank Portfolio Allocation: The Impact of Capital Requirements, Regulatory Monitoring, and....," J. Financ. Serv. Res., vol. 20, no. 1, p. 33, Sep. 2001.

[15] T. B. King, "Discipline and Liquidity in the Interbank Market," J. Money Credit Bank., vol. 40, no. 2/3, pp. 295-317, Mar. 2008.

[16] E. D. Tovar-García, "Who Can Better Monitor a Bank than Another Bank? Mechanisms of Discipline in the Mexican Interbank Market // ¿Quién mejor que un banco para monitorear otro banco? Mecanismos de disciplina en el mercado interbancario mexicano," Rev. Métod.
Cuantitativos Para Econ. Empresa, vol. 21, p. áginas 205 a 229-áginas 205 a 229, Nov. 2016.

[17] E. D. Tovar-García, "Exposure to interbank market and risk-taking by Mexican banks," Cuad. Econ., vol. 39, no. 111, pp. 157-174, Sep. 2016, doi: 10.1016/j.cesjef.2015.11.002.

[18] E. L. P. Yeyati Maria Soledad Martinez Schmukler, Sergio, Market Discipline under Systemic Risk: Evidence from Bank Runs in Emerging Economies. The World Bank, 2004. doi: 10.1596/1813-9450-3440.

[19] G. Phung, "Making Depositors Greedy and Careless: Government Safety Nets and the Degradation of Depositor Discipline," SSRN Electron. J., 2018, doi: 10.2139/ssrn.3190281.

\section{Contribution of Individual Authors to the Creation of a Scientific Article (Ghostwriting Policy)}

Author Contributions:

Dung Viet Tran and Chi Huu Lu equally contributed to this study.

\section{Sources of Funding for Research Presented in a Scientific Article or Scientific Article Itself}

Not applicable.

\section{Creative Commons Attribution License 4.0 (Attribution 4.0 International, CC BY 4.0)}

This article is published under the terms of the Creative Commons Attribution License 4.0 https://creativecommons.org/licenses/by/4.0/deed.en US 